\title{
Hypomyelination-congenital cataract syndrome
}

INSERM

\section{Source}

INSERM. (1999). Orphanet: an online rare disease and orphan drug data base.

Hypomyelination-congenital cataract syndrome. ORPHA:85163

Hypomyelination-congenital cataract is characterized by the onset of cataract either at birth or in the first two months of life, delayed psychomotor development by the end of the first year of life and moderate intellectual deficit. 